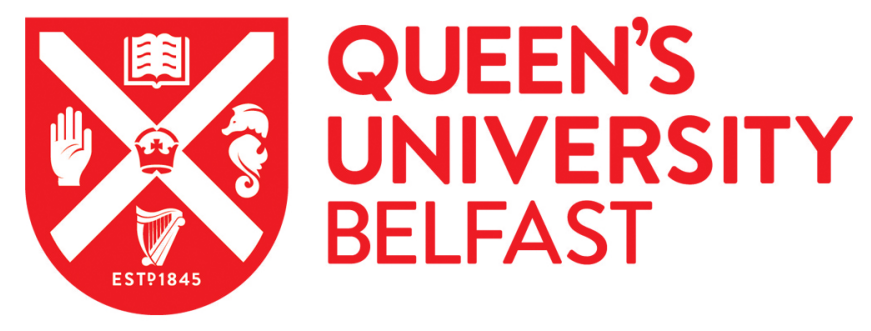

\title{
From I to we: Participants' accounts of the development and impact of shared identity at large-scale displays of Irish national identity
}

Blaylock, D. L., Stevenson, C., O’Donnell, A. T., Reicher, S. D., Bryan, D., Neville, F. G., \& Muldoon, O. T. (2021). From I to we: Participants' accounts of the development and impact of shared identity at large-scale displays of Irish national identity. Irish Political Studies, 36(1), 92-108.

https://doi.org/10.1080/07907184.2021.1877896

Published in:

Irish Political Studies

Document Version:

Publisher's PDF, also known as Version of record

Queen's University Belfast - Research Portal:

Link to publication record in Queen's University Belfast Research Portal

Publisher rights

Copyright 2021 the authors.

This is an open access article published under a Creative Commons Attribution License (https://creativecommons.org/licenses/by/4.0/), which permits unrestricted use, distribution and reproduction in any medium, provided the author and source are cited.

\section{General rights}

Copyright for the publications made accessible via the Queen's University Belfast Research Portal is retained by the author(s) and / or other copyright owners and it is a condition of accessing these publications that users recognise and abide by the legal requirements associated with these rights.

Take down policy

The Research Portal is Queen's institutional repository that provides access to Queen's research output. Every effort has been made to ensure that content in the Research Portal does not infringe any person's rights, or applicable UK laws. If you discover content in the Research Portal that you believe breaches copyright or violates any law, please contact openaccess@qub.ac.uk. 


\section{From I to we: participants' accounts of the development and impact of shared identity at large-scale displays of Irish national identity}

\section{Danielle L. Blaylock, Clifford Stevenson, Aisling T. O'Donnell, Stephen D.} Reicher, Dominic Bryan, Fergus G. Neville \& Orla T. Muldoon

To cite this article: Danielle L. Blaylock, Clifford Stevenson, Aisling T. O'Donnell, Stephen D. Reicher, Dominic Bryan, Fergus G. Neville \& Orla T. Muldoon (2021) From I to we: participants' accounts of the development and impact of shared identity at large-scale displays of Irish national identity, Irish Political Studies, 36:1, 92-108, DOI: 10.1080/07907184.2021.1877896

To link to this article: https://doi.org/10.1080/07907184.2021.1877896

\section{(c) 2021 The Author(s). Published by Informa UK Limited, trading as Taylor \& Francis Group}

\section{Published online: 12 Feb 2021.}

Submit your article to this journal $₫$

Џ Article views: 132

Q View related articles $\sqsubset$ 


\title{
From I to we: participants' accounts of the development and impact of shared identity at large-scale displays of Irish national identity
}

\author{
Danielle L. Blaylock ${ }^{\mathrm{a}, c}$, Clifford Stevenson ${ }^{\mathrm{b}}$, Aisling T. O'Donnell ${ }^{c}$, Stephen \\ D. Reicher ${ }^{\mathrm{d}}$, Dominic Bryan ${ }^{\mathrm{e}}$, Fergus G. Neville ${ }^{\mathrm{f}}{ }^{\mathrm{f}}$ and Orla T. Muldoon (i) ${ }^{\mathrm{c}}$
}

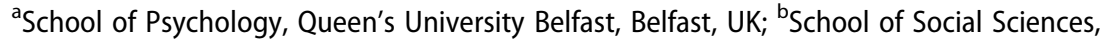
Nottingham Trent University, Nottingham, UK; ' Department of Psychology, University of Limerick, Limerick, Ireland; ${ }^{d}$ School of Psychology and Neuroscience, University of

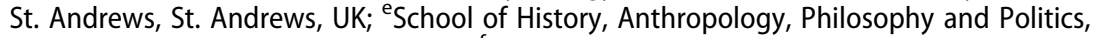
Queen's University Belfast, Belfast, UK; ${ }^{\text {f S}}$ School of Management, University of St. Andrews, St. Andrews, UK

\begin{abstract}
In Ireland, ritual events and parades have been a central part of civic and public life. However, there is limited understanding of the identity processes at work at these collective events. The present research aims to examine how participants attending collective events come to recognise shared social identification and the impact that this awareness is reported to have on intragroup processes. Interview data were collected over the course of two years at the St Patrick's Day parade and 1916 Easter Rising commemorations in Dublin and Belfast with both participants and attendees at the events. Thematic analysis revealed that to the extent that individuals saw the event as an identity event, they used attendance as their primary indication of shared identity, along with visual identity markers, shared experiences, and shared affects. Participants' accounts of the experience of shared identity focused upon a range of cognitive, affective, and social variables which together suggested a relational transformation in the crowd. These findings suggest that shared identity is an emergent state which plays a critical role in transforming social relations within the collective.
\end{abstract}

KEYWORDS Collective experience; collective participation; crowd events; shared identity; social identity; parades; ritual; Ireland; St Patrick's Day; Easter Rising

\section{Introduction}

In Ireland issues of national identity, specifically the shared understanding of belonging to a distinctive national community and political project, have been central to politics north and south, particularly since the nineteenth 
Century (Coakley, 2002). And in a related literature, it has been widely accepted that national celebratory and commemorative events play an important role in reflecting and contesting these understandings of Irishness (e.g. Daly, 2004; White \& Marnane, 2016). A wide range of studies have sought to chronicle the historic and contemporary manifestations of commemorations and collective events. The potential of collective behaviour to embody and enact shared identities as well as the power of collective events to both reproduce and transform these identities is now increasingly acknowledged (Drury \& Reicher, 2009; O'Donnell et al., 2016). The reproduction of collective understandings of Irishness has important political dimensions as it speaks to who is (and is not) understood to be part of the national community. In this paper, we bring these two issues together to explore whether shared understandings of Irish identity are (re)produced by participants at collective events north and south of the border, and consider how they speak to contemporary understandings of Irishness.

That collective events play an important part in the general social life of the nation is acknowledged (Frijda, 1997). In Ireland, the importance of 1916 commemorations in establishing the historical continuity of Irish national identity (e.g. see Daly \& O'Callaghan, 2007; White \& Marnane, 2016) as well as St Patrick's Day in creating new international and cosmopolitan understandings of Irishness (e.g. see Cronin \& Adair, 2002) is now widely documented. These studies have focussed on the specific details relating to these events and their symbolic significance. Our study adds to this literature by offering the systematic study of participants' and audience views of events. Therefore, in this paper, we explore how Irish national identity is understood amongst participants and those in attendance at St Patrick's Day and the Easter commemoration events in Belfast and Dublin. Our central aim is to explore how the events facilitate participants to recognise, shape and articulate a shared sense of Irish national identity.

Previous research has shown that crowd and collective events have the potential to facilitate a sense of shared identity even at large events (Neville \& Reicher, 2018; O'Donnell et al., 2016). This sense of shared identity may be likely to arise in particular contexts. First, the mere fact that people are co-present, undertaking the same activity and observing the same rituals, may lead to an assumption of shared identity (Prayag Magh Mela Research Group, 2007). Second, shared experience may lead to a sense of shared identity (Bradshaw \& Muldoon, 2019; Kearns, Muldoon, Msetfi, \& Surgenor, 2017). This may be something as benign as the experience of commuters on a train that breaks down (Neville, 2011), or as serious as the experience of commuters on a train that has been bombed (Cocking, Drury, \& Reicher, 2007). Third, historians, sociologists and (latterly) psychologists have suggested that the various forms of physical coordination which occur at collective events marching in step, chanting slogans - may help consolidate and help people to imagine themselves as sharing a common identity (e.g. Ehrenreich, 2007). 
Fourth, shared symbols - the fact either that people bear the same symbol or react similarly to a symbol, say by singing an anthem, joining a chant or saluting a flag - are often the basis for creating a sense of shared identity (Ross, 2007). Moreover, a key theme of work on symbolism is the fact that a sense of unity can be created by common reactions to a symbol, even where (or indeed particularly because) it is ambiguous and means very different things to different people (Cohen, 1985; Muldoon, Trew, \& Devine, 2020).

More recently, Neville and Reicher (2018) have highlighted how it is a sense of shared identity - the sense that I see others as a member of my group, and they in turn see me and each other as members of this group - which is essential for a relational shift towards intimacy, support and the ability to co-act. This sense of shared identity then fundamentally transforms social relations at collective events (Neville \& Reicher, 2018). This transformed sense of relations between individuals within a group allows them to act together more harmoniously and effectively (Reicher \& Haslam, 2010). In this way collective events and any associated sense of shared identity can be seen as a potent socio-political force. Reflecting the relevance of shared identity to the study of politics, issues of shared identity and relational transformations have attracted interest in the analysis of social change in Ireland and elsewhere (Todd, 2005). In addition, Drury and Reicher (1999) theorise that the emergence of shared identity underpins the confidence, ability, and willingness of crowd members to work together to reach their goals. Moreover, of course, evidence of an available shared national identity implies that this identity resource is available to those who can mobilise it for political gain.

In this study, we focused on four different annual events on two different occasions in 2009 and 2010. These events, St Patrick's Day and the Easter Rising commemoration, are popularly recognised to be displays of Irish national identity. We purposefully studied them, north and south of the border, as it offered two very different socio-political contexts. In Northern Ireland, contentious parades and collective gatherings associated with Loyalism and Orangeism have garnered research interest (McAuley \& Tonge, 2007); however, identity-based crowd events associated with Irishness have attracted less interest. Moreover, national identity and more specifically Irishness have very different meanings in Northern Ireland and the Irish Republic (Muldoon, Trew, Todd, Rougier, \& McLaughlin, 2007; Stevenson \& Muldoon, 2010). National identity in Northern Ireland is contested. And claiming Irishness can be seen as divisive and the claim itself can be seen by other group members to undermine the authenticity of national group membership (Stevenson \& Muldoon, 2010). In the Irish Republic on the other hand, Irish national identity is a banal group membership assumed by the majority. Like many national identities it has ethno-religious undertones and national group members who do not share ethnic or religious group membership with the majority can feel their national identity credentials are undermined 
(Fahey, Hayes, \& Sinnott, 2005). In short, we expected the collective understandings of Irish national identity and any sense that it may be a shared identity to be challenging in both jurisdictions.

In Dublin and in Belfast we explored how participants and audience at the St Patrick's Day parade and 1916 Easter Rising commemorations spoke about Irishness. For most, St Patrick's Day is seen as a fun and carnivalesque event, which ultimately is Irish (Skinner \& Bryan, 2015). The increasingly visible St Patrick's Day Festival in Dublin has facilitated this. The event draws large numbers of participants and attendees from all over the world. The event strives to be inclusive, and is centrally concerned with integration of immigrants and 'new Irish' (Pehrson, Stevenson, Muldoon, \& Reicher, 2014). In Belfast since 2005, Belfast City Council has also run a St Patrick's event. The Council has sought to define its event as inclusive and as equally welcoming to all, though in this case inclusion is linked to encouraging participation and spectators from both sides of the religious divide (O'Donnell et al., 2016).

The commemoration of the Easter Rising is a more sombre affair, which marks the anniversary of the uprising of 1916. Commemorations on Easter Sunday in Dublin are held to pay tribute and as a celebration of an independent Irish state in the Republic. In Northern Ireland, it is an occasion to signify what some may see as an on-going struggle for a united 32 county Republic of Ireland. In this way the commemoration of 1916 is particularly linked to contemporary Irish republicanism in Belfast (Browne, 2016). In Dublin the commemorations we studied were in the years prior to the centenary commemoration (2009 and 2010). These were years in which the Department of the Taoiseach worked to establish this event as a national and state sponsored homage to Irishness. Reflecting complexity and territoriality, this management of the 1916 commemoration by the state in Dublin can be seen as taking ownership of this event from one group of Irish people, namely republicans (Bean, 2014; Higgins, 2012).

Clearly, these four different collective events are not equivalent. The nonequivalence of these events can be seen as central to our purpose. The value of a national political project is without question in its ability to include all in the national project. However, in both the north and south the social and political change in the national landscape and national group membership across the first decade of the twenty-first century was substantial. In Northern Ireland, the rise in the proportion of people describing themselves as Northern Irish, rather than British or Irish, was substantial in the wake of the Good Friday Agreement (Lowe \& Muldoon, 2014). And in the Irish Republic, the same decade saw the first ever wave of inward migration and the associated challenges of social integration of non-Irish nationals and multiculturalism. Therefore, our data allow us to interrogate whether participants can reconstruct and manage a sense of a collective national identity across these very different events, north and south. We undertook an analysis of the 
various ways in which participants in an event do (or do not) see themselves as sharing Irish identity with others and the various aspects of crowd experience that are associated with this.

\section{Method}

\section{Participants}

Data were drawn from a body of 521 semi-structured interviews conducted either before and/or after or onsite during the events with individuals either attending or participating in one of the four events in 2009 or 2010. Respondents were recruited with a view to ensure maximum sample diversity in terms of age, socioeconomic status, ethnicity, and (in Belfast in particular) political and religious backgrounds.

\section{Strategy and procedures}

Most of our data collection was conducted onsite, during the events we were studying. In 2009 (year 1), we talked to 203 people and, in 2010 (year 2) we talked to 265 people. For practical reasons, onsite vox-pop interviews were brief and lasted roughly two minutes. The aim of the interviews was to allow participants to talk about their experiences of the event in their own words. The questioning was open - we did not ask explicitly about shared identity unless participants raised it. However, whereas in year 1 we simply asked people to talk about their impressions of the event, in year 2 we also asked them to comment on relations between people in the crowd.

We complemented this data with a number of longer, more in-depth interviews in year 1 . These lasted between 30 and $90 \mathrm{~min}$. Twenty people were interviewed both before and after an event, a further 13 were interviewed either before ( 5 interviews) or after ( 8 interviews) an event. These participants were recruited through organisations that were participating in or managing the events. All interviews began with a general prompt about what people expected of the event (pre-interviews) or what they had experienced in the event (post-interviews). They were then invited to reflect upon either their expectations or else their experience of feelings, events, and interactions with other attendees.

\section{Data analysis}

Consistent with previous social identity research into crowd events (Drury \& Reicher, 1999; O'Donnell et al., 2016), a thematic analysis was employed. In the absence of a large body of previous research, the development of a priori strategies regarding the direction of the analysis would be counterproductive (Pidgeon \& Henwood, 1997). A thematic analysis is thus ideally suited 
because of its flexibility and bottom-up nature, allowing analytic themes to emerge inductively from the data themselves. Additionally, a thematic analysis has the advantage of providing an insider's perspective, particularly useful for understanding the factors contributing to an awareness of shared identity.

All interviews were audio-recorded, transcribed verbatim and indexed using ATLAS.ti software. The sections relevant to our research concerns were identified within the context of their occurrence in the interviews and subjected to a thematic analysis following the guidelines set out by Braun and Clarke (2006) while using the method of constant comparison to derive patterns of response types across the full data set (Glaser \& Strauss, 1967). These procedures allow for active engagement with the data in a close and rigorous examination.

The first stage of analysis involved identifying all sections broadly related to the antecedents and consequences of a shared identity. The data corpus was read and reread, and sections related to shared identity were used to create our dataset. Key segments within each of these sections were then identified and descriptive categories were developed based upon common features. This process was facilitated with the use of memo-writing and consensus building between members of the research team in a method of opencoding (Charmaz, 1995).

Through further discussion and negotiation our initial descriptive categories were further examined and both sub-categories and higher order categories were identified. Next, sub-categories were related to higher order categories in a process of axial coding (Strauss \& Corbin, 1998). This process was facilitated by a comparison of both positive and negative examples of shared identity found within the data, and this led to the development of a taxonomy of response types across the data. Establishing relationships between categories represented a movement from the descriptive to the conceptual. At this stage of the data analysis, theoretical saturation occurred when no new data emerged for the categories and the categories were dense enough to cover all variations and relationships (Willig, 2001).

\section{Analysis}

Participants talked about shared identity in two ways. On the one hand they talked about various pieces of evidence which led them to infer that people saw each other as sharing (or not sharing) a common identity. On the other hand, they linked shared identity (or its absence) to the ways that they experienced an event and the nature of social relations between members of the crowd. Accordingly, our analysis is divided into two parts, the first dealing with recognition of shared identity, the second dealing with the correlates in terms of crowd experience and relations between crowd members. 


\section{Recognition of shared identity}

Attendance ( $N=127$ extracts). Perhaps most simply and straightforwardly, people inferred shared identity from mere attendance at an event. Thus, if you turn up to an Irish republican event, you must be (and think of yourself) as an Irish republican. This is the case of our first extract:

Extract 1: (Belfast 1916, pre-event interview, male) 'Just a lot of Irish republicans'

It is worth noting that shared identity here is not about uniformity. People can be Catholic or they can be Protestant (lines 1-3). What matters is that they are Irish republicans and that is inferred from participation. But some notes of qualification are necessary here. In this extract, participation is not simply about 'being there'. It is also about participating in the ritual of the event paying one's respects to those viewed as martyrs for the cause (lines 7-8). The respondent refers specifically to those who 'on that Sunday will march up to Milltown' (line 7). Milltown cemetery is a republican space, especially on Easter Sunday, where intruders might fear to tread (Smyth, 2017). For example, in March 1988, two British soldiers in plain clothes whose car became entangled in a funeral procession heading to Milltown were attacked and killed.

Symbolism ( $N=84$ extracts). If attendance is an important but ambivalent criterion of shared identity, it is often complemented by symbolism - that is, people are seen as fellow group members not simply because they are participants but also because they come bearing symbols of identity.

All the events we attended were replete with symbolism. Anyone attending a St Patrick's Day celebration, regardless of location, would be struck by the displays of iconically 'Irish' symbols: shamrocks, leprechauns, and the colour green. Although the symbols are more specifically political, this is also true of the 1916 Easter Rising commemorations, particularly the Sinn Féin events in Dublin and Belfast. For Irish republicans, the Easter lily is seen as a symbol of remembrance for those who were executed during the 1916 Easter Rising or who have subsequently died for Irish independence since. Only a republican would wear the lily:

Extract 2: (Dublin 1916, onsite interview, male) 'Everybody here wearing a lily feels the exact same way I do'

It is clear throughout the extract that attendance is insufficient to denote shared identity. Thus, the state celebration might say something about Irishness, but it does not say anything about being republican, which is the identity that is of importance to this respondent. That is why he is attending a Sinn Féin event where, it is implied, others are likely to share his republicanism. But 
even here, as is made clear in lines $2-4$, one cannot be sure that everyone is a republican and hence the sense of commonality does not apply to everybody, but rather to 'everybody here wearing a lily'.

Implicit in this extract, then, is not only that symbols create shared identity but also that symbols can denote a lack of shared identity, or even the existence of opposed identities. This can either be because people are not bearing ingroup symbols, or because they are bearing outgroup symbols. This is particularly apparent in the Belfast St. Patrick's Day event, where there is a controversy over whether the event is about an inclusive Irishness or about a primary Catholic nationalist identity. Here, the Irish tricolour, as a symbol of a nationalist vision of a united Ireland, is controversial and denotes a division in the crowd. It thereby symbolises a lack of shared identity as shown in the following extract:

Extract 3: (Belfast St Patrick's Day, onsite interview, male) 'He did not feel part of $i t^{\prime}$

Thus far, we have concentrated on how symbols serve to indicate that others share the same identity as oneself. Yet, this is still not quite sufficient for a sense of shared identity which is about crowd members seeing each other as having the same identity. Part of that is indeed about seeing others as having one's identity. But equally, it is important that others see one as sharing their identity. Only then can one expect solidarity and support from them. Symbols are one way in which people can clearly signal their membership to others:

Extract 4: (Belfast St Patrick's Day, onsite interview, female) 'You just stand out in a crowd if you are not wearing the colours'

Here, wearing green is a conscious strategy of being seen to fit in - or at least not to stand out. It is clear here that this is a strategy used by people who could be seen as outsiders ('tourists' - line 5) and who therefore were unsure as to whether they would be accepted at the event ('I'Il just mingle and see what happens' - line 4). It is clear also that the strategy is seen to be successful. The respondent sees herself as part of a crowd of green and that feels 'lovely' (line 8).

Shared experience/shared fate ( $N=52$ extracts). If the previous sections addressed the inference that certain types of people - as denoted by their presence or their symbols - have come together in the crowd (what Turner and Killian (1972) term a 'convergence' approach to crowds), here we address the assumption that anyone who shares the same crowd experiences will end up with the same identity. That is, shared identity is an emergent property that affects anyone and not a reflection of the prior dispositions of particular people. 
Extract 5: (Dublin St Patrick's Day, pre-event interview, female) 'We are all experiencing the same thing at the same time and its really powerful that everybody is the same'

Once again, it is notable that a sense of shared identity co-exists with an acknowledgement of diversity - indeed the power of shared experience in creating shared identity is precisely because of its inclusiveness of diversity. This is also true of the next extract, although here diversity is a matter of opinions rather than of ethnicity. Common experience is also a matter of the past as well as the present:

Extract 6: (Belfast 1916, onsite interview, female) 'We've all experienced the same thing'

In both these extracts, shared experience is something that is inferred from the fact that people have gone through the same events. There is no reference to direct evidence that people do indeed think or feel about these events in the same way. As we shall see in the next section, however, respondents do often scrutinise such evidence to make judgements about shared identity.

Shared affect ( $N=63$ extracts). When respondents looked for direct signs that others experienced events in the same way, they referred to affect. Emotion was read from the expressions, movements and actions of others and respondents used this information to determine whether or not there was a commonality between themselves and others:

Extract 7: (Belfast St Patrick's Day, onsite interview, year 2, R1 female, R2 male) 'Everybody's jolly'

Here, the two respondents, R1 and R2 affirm that shared positive emotion is the sign of commonality. For added emphasis they each corroborate the other using synonyms to make the same point ('jolly', 'happy', 'good spirits' - lines 6-8).

However, it is not just about showing a generic emotion, but about showing the same appropriate emotion to the same event. Thus, in the following extract, taken from the Easter Sunday commemoration in Dublin, what is important is that people show a common emotion of pride when mention is made of the republicans who had died in the independence struggle:

\section{Extract 8: (Dublin 1916, onsite interview, male) 'Sense of pride'}

The corollary of this is that different emotions will be appropriate to different events and at different points within events. For instance in extract 9 below, a sense of inclusion derives from the observation of a common event (people passing by with pictures of their dead republican relatives), but this, in turn, is important because of the common empathic emotion (being touched - line 
4) invoked in other observers. In this context, it is sadness not happiness that binds people together:

Extract 9: (Belfast 1916, onsite interview, female) 'Touches a lot of people'

\section{Crowd experience and shared identity}

The second set of themes emergent from the analysis had to do with the way that shared identity relates to a series of other phenomena - cognitive, motivational, affective, and behavioural. Here we see how the phenomena which serve as antecedents to the perception of shared identity can also be seen as consequences or correlates.

Consensus ( $N=94$ extracts). As shared identity became salient, participants perceived members of the crowd as holding attitudes and beliefs that were congruent with the ingroup and, as an extension, expected agreement. The following extract is particularly rich in this regard:

Extract 10: (Dublin St Patrick's Day, onsite interview, female) 'We're all here to celebrate the one thing'

Here, the criterion for perceiving shared identity are symbolic - the wearing of the green (lines 3-4). From this it is inferred, first, that people have the same purposes (to celebrate Irishness - lines 2-3), the same feelings (of pride - line 5) and the same motivations (to integrate into Irish society - lines 7-8). Shared identity is associated with the assumption that there is a coincidence of thoughts and feelings. But it is not absolute and does not (as we have seen on multiple occasions) rule out diversity. Rather, it is about the fact that people are coincident specifically in their Irishness: they are committed to Ireland, they feel good about their connection to Ireland. In this sense, their lay assumptions coincide with a core theoretical premise of self-categorisation theory - that group members expect and achieve consensus around matters of relevance to group identity (Turner, 1991).

Cohesion ( $N=116$ extracts). In many ways, though, what is most interesting is not the assumption of consensus itself, but what flows from that assumption. People who feel that they share so much in common with others, especially those things which count in context (that is, identity-relevant feelings and beliefs) thereby feel at ease and at home with others. Words like 'belonging' and 'comfort' were used frequently in our corpus. This was even true for participants who normally would not be considered to belong on any other occasion:

Extract 11: (Dublin St Patrick's Day, onsite interview, female) 'It feels like I belong here'

Another aspect of this sense of commonality was the description of relations with others as intimate. Others were often described as 'comrades' and 
'brothers'. Indeed, as illustrated from the next extract, the metaphor of family in its various guises was a powerful way of encapsulating a close set of social relations in which people accept, support, and embrace each-other:

Extract 12: (Belfast 1916, pre-event interview, female) 'I feel part of a wider family'

There is a corollary, however:

Extract 13: (Belfast 1916, onsite interview, female) 'I feel like I'm an outsider' Here, lacking a shared identity ('I don't take one side or the other when it comes to Irish politics' - line 5-6) and hence lacking a shared perspective ('I definitely don't share their views' - lines 7-8) leads to a sense of exclusion ('I definitely don't feel I'm a part of this' - lines 6-7) and of alienation from those around them ('I feel like I'm an outsider' - line 7).

Affect ( $N=57$ extracts). Shared emotion is used as a criterion of shared identity; where people see shared identity, they assume people will have shared emotion. Vice versa, where people share the same emotion they are assumed to share identity. However, the complex role of emotional expression is also evident in the way individuals experience positive and intense emotions as a response to perceived shared identity which is illustrated in this, our final extract:

Extract 14: (Dublin 1916, onsite interview, male) 'It is visceral' Here, the notion that one is intimately linked to others, that one is thinking and feeling as they do about matters of common importance ('something you believe in' - line 8), is in itself a strongly positive experience. It is a passionate experience. In short, we see here a cycle of intensification whereby the perception of shared experience (positive experience in particular) strengthens those experiences and renders them distinctively - perhaps uniquely - powerful. This power is eloquently expressed in line 5. Asked to confirm that the crowd experience is 'visceral', the respondent is not content with a mere 'yes', rather he underlines the point with: 'Yeah. Oh yeah' (line 5).

\section{Discussion}

The findings of our interviews highlighted that common experience, emergent intimacy and collective joy are all aspects of the events we examined. Shared identity was not just of interest to us as theorists, it was also a concern for our respondents. The existence or absence of shared identity was always in question and was something towards which participants at collective events orientate to consciously. This was evidenced by the number of mentions in our interviews (some of which were spontaneous and some of which were cued by the 
questioning) but also by the fact that, as we explored the issue, people found it very easy to discuss if they inferred shared identity and what they inferred from shared identity. Shared identity was not simply something that was taken as a given at these collective events. Rather there was good reason to suggest that, even if the parameters feeding into them are different at differing events, sharedness and its presence or absence are common underlying processes that are used to recreate or reject a sense of shared Irish national identity.

We found two different ways participants orientate to the issue. On the one hand, various aspects of the crowd were used as criteria to claim or establish that a shared identity exists (or is lacking). Criteria for the perception of shared identity included (a) participation in an event - particularly where presence is not something one would expect of the uncommitted and also where participation denotes observance of collective rituals as well as mere attendance; (b) participants wearing appropriate symbols and not divisive symbols; (c) all sharing the same experiences; (d) all expressing the same emotions. As we have seen, it is not only that satisfaction of these criteria led to the inference of shared identity but also violation of the criteria led to the inference that it is lacking.

In many ways, though, what is most interesting is not the assumption of consensus and sharedness, but what flows from that assumption. The perception of shared identity was associated with a number of outcomes. It was associated with an assumption that those present (including oneself) share the same thoughts and feelings, specifically about group-related matters. This sense of commonality is associated with a feeling that one will be accepted by others. Furthermore, the sense of commonality is a source of positive feeling and of passionate experience. Our previous work suggests that this type of positive experience is likely to have a positive consequence for the health of participants (Kearns et al., 2017) and it is also likely to contribute to a stronger sense of national identity (O'Donnell et al., 2016). However what sharedness means and what forms of sharedness are promoted or desired appear to differ across events. In contemporary Ireland, shared identity transcends or at least masks the divisions within the national group. In this way, the collective events we studied can be seen to support Irishness as a political project on both sides of the border.

These findings extend existing theory. It is of value to show that people consider multiple criteria and multiple outcomes. And our findings emphasise certain factors such as emotion which, if not neglected, are certainly underplayed when dealing with shared identity (though not collective action more generally; see van Zomeren, Leach, \& Spears, 2012). Additionally, our findings highlight how shared experience and shared emotion can serve both as an input to and a consequence of shared identity. Our method helps us see how they are part of a coherent process of amplification that builds in 
crowd events; something that Blumer captured in his notion of a 'circular reaction' (1957).

What is most distinctive about our findings, however, is the meta-representational dimension. That is, it is not just that shared identity is associated with shared cognition and emotion, but also that it associated with an awareness of sharing. And, moreover, this awareness is itself critical to the ensuing dynamics for it leads to a sense of intimacy and an enhanced positivity. This emotional positivity, which Durkheim (1915/2008) famously referred to as 'effervescence' is one of the most noted aspects of crowd psychology; however, traditionally, it has been viewed as resulting from a loss of identity and judgement (Le Bon, 1896/1947). What we see here, by contrast, is that such powerful emotions are bound up with collective identity and also multiple layers of cognition. While this link between shared identity, shared cognition/emotion, intra-group intimacy and collective passion has been offered before (Reicher, 2011, 2012), here is empirical corroboration. Indeed, one of the strongest forms of evidence we have is that when certain criteria are violated, people do not perceive there to be shared identity, they do not perceive there to be shared thoughts or shared feelings, and they do not express effervescent emotionality. Indeed, their experience is more one of disillusion and alienation.

Future research in this space is warranted. The relative contribution of the different constructs we have identified is not fully understood. Most obviously, when are the different antecedents of perceived shared identity more or less important? Thus, for instance, attendance may be of greater import the greater the costs involved (Neville, 2011). Moreover, what happens when different criteria point in different directions - say people wearing the same symbols but displaying divergent emotional reactions to events? These are questions that remain to be addressed - but, once again we would emphasise, they are questions which are only generated when one adopts a holistic approach to actual events.

To conclude, there are three things to take away from this study. The first is conceptual: it is important to distinguish the objective reality of shared identity from the self-conscious awareness of shared identity amongst crowd participants, and to acknowledge that these may have both different antecedents and different consequences. The second is theoretical: the study suggests that the self-conscious awareness that 'we' all see ourselves and each other as common group members not only leads to intra-group intimacy but also to an intense pleasure in that intimacy. In other words, our findings complement the ideas of others (Prayag Magh Mela Research Group, 2007; Reicher, 2011) in suggesting that we may have an explanation of one of the most striking and enigmatic aspects of the crowd - effervescence (Ehrenreich, 2007). 
The third is practical: understanding the bases of shared identity is critical to the design of collective events and building supportive social relations. As noted above, St Patrick's Day in Belfast and in Dublin are proactively promoted by their respective governments as sites of inclusion and 'good relations' between groups. Our work suggests that crowd events are potentially a site where collective identity can be actively fostered and enhanced, allowing the potential promotion of the psychological benefits of collective belonging. For instance, the use of symbols in which all can invest - and avoiding symbols which will be seen as denoting an outgroup by some may be critical (Bryan, 2009; Cronin \& Adair, 2002). All in all, developing our understanding of perceived shared identity is critical to understanding and achieving cohesion and solidarity.

\section{Disclosure statement}

No potential conflict of interest was reported by the author(s).

\section{Funding}

This research was supported by matched grants from the Irish Research Council and the Economic and Social Research Council (RES-062-23-1140).

\section{Notes on contributors}

Dr. Danielle L. Blaylock is a Lecturer in the School of Psychology at Queens University Belfast. Her research focuses on intergroup relations, intergroup conflict and social change in divided societies and is closes associated with social identity theory and contact theory.

Prof Clifford Stevenson is a Professor of Social Psychology at Nottimgham Trent University. His research examines how the groups to which people belong serve to shape their perception and experience of social reality.

Dr. Aisling T. O'Donnell is a Lecturer in Psychology at the University of Limerick. Her research expertise relates to social identity processes, including relationships within and between groups, how identity is constructed and understood, and how it relates to well-being.

Prof Stephen D. Reicher is a Professor of Psychology at University of St Andrews. Broadly his research addresses the issues of group behaviour and the individualsocial relationship.

Prof Dominic Bryan is a Professor of Anthropology at Queens University Belfast. Broadly his research examines the nature of intergroup conflict on the symbolic landscape. It has particularly looked at the role played by symbols and rituals during the conflict and peace in Northern Ireland.

Dr. Fergus G. Neville is a Lecturer in Organisation Studies at University of St Andrews. Broadly his research focusses on group processes and their prosocial and anti-social consequences. 
Prof Orla T. Muldoon is Professor of Psychology at University of Limerick. Her research interests relate to how system and structures impact on social, psychological and political functioning.

\section{ORCID}

Fergus G. Neville (D) http://orcid.org/0000-0001-7377-4507

Orla T. Muldoon (D) http://orcid.org/0000-0001-9082-2443

\section{References}

Bean, K. (2014). Endings and beginnings? Republicanism since 1994. Studies in Conflict \& Terrorism, 37(9), 720-732.

Blumer, H. (1957). Collective behavior. In J. Gittler (Ed.), Review of sociology: Analysis of a decade (pp. 127-158). New York: John Wiley and Sons.

Bradshaw, D., \& Muldoon, O. T. (2019). Shared experiences and the social cure in the context of a stigmatized identity. British Journal of Social Psychology. doi:10.1111/ bjso. 12341

Braun, V., \& Clarke, V. (2006). Using thematic analysis in psychology. Qualitative Research in Psychology, 3, 77-101. doi:10.1191/1478088706qp0630a

Browne, B. C. (2016). Choreographed segregation: Irish republican commemoration of the 1916 Easter Rising in 'post-conflict' Belfast. Irish Political Studies, 31(1), 101-121.

Bryan, D. (2009). Negotiating civic space in Belfast or the tricolour: here today, gone tomorrow. Working paper No. 13 (referred) Conflict and Cities and the Contested State Project http://www.conflictincities.org/workingpapers.html.

Charmaz, K. (1995). Grounded theory. In J. A. Smith, R. Harré, \& L. V. Langenhove (Eds.), Rethinking methods in psychology (pp. 27-48). London: Sage.

Coakley, J. (2002). Religion, national identity and political change in modern Ireland. Irish Political Studies, 17(1), 4-28.

Cocking, C., Drury, J., \& Reicher, S. D. (2007). The psychology of crowd behaviour in emergency evacuations: Results from two interview studies and implications for the fire \& rescue service. Irish Journal of Psychology, 30, 59-73.

Cohen, A. P. (1985). The symbolic construction of community. New York: Tavistock.

Cronin, M., \& Adair, D. (2002). The wearing of the green: A history of St. Patrick's Day. New York: Routledge.

Daly, M. (2004). History à la carte? Historical commemoration and modern Ireland. In E. Borte (Ed.), Commemorating Ireland: History, Politics, Culture (pp. 34-55), Dublin: Irish Academic Press.

Daly, M. E., \& O'Callaghan, M. (2007). 1916 in 1966: Commemorating the Easter Rising. Dublin: Royal Irish Academy.

Drury, J., \& Reicher, S. (1999). The intergroup dynamics of collective empowerment: Substantiating the social identity model of crowd behaviour. Group Processes \& Intergroup Relations, 2, 381-402. doi:10.1177/1368430299024005

Drury, J., \& Reicher, S. (2009). Collective psychological empowerment as a model of social change: Researching crowds and power. Journal of Social Issues, 65, 707-725.

Durkheim, E. ([1915] 2008). The elementary forms of the religious life: $A$ study in religious sociology. (J. W. Swain, Trans.). New York: Macmillan.

Ehrenreich, B. (2007). Dancing in the streets: A history of collective joy. New York: Metropolitan. 
Fahey, T., Hayes, B. C., \& Sinnott, R. (2005). Conflict and consensus: A study of values and attitudes in the Republic of Ireland and Northern Ireland. Dublin: Institute of Public Administration.

Frijda, N. H. (1997). Commemorating. In J. W. Pennebaker, D. Paex, \& B. Rime (Eds.), Collective memory of political events: Social psychological perspectives ( $\mathrm{pp}$. 103130). Mahwah, NJ: Erlbaum.

Glaser, B. G., \& Strauss, A. I. (1967). The discovery of grounded theory. New York: Aldine.

Higgins, R. (2012). Transforming 1916: Meaning, memory and the fiftieth anniversary of the Easter rising. Cork University Press.

Kearns, M., Muldoon, O. T., Msetfi, R. M., \& Surgenor, P. W. (2017). Darkness into light? Identification with the crowd at a suicide prevention fundraiser promotes wellbeing amongst participants. European Journal of Social Psychology, 47(7), 878-888.

Le Bon, G. (1896). The Crowd. London: Fisher Unwin.

Lowe, R. D., \& Muldoon, O. T. (2014). Shared national identification in Northern Ireland: An application of psychological models of group inclusion post conflict. Group Processes \& Intergroup Relations, 17(5), 602-616.

McAuley, J. W., \& Tonge, J. (2007). "For God and for the Crown": contemporary political and social attitudes among Orange order members in Northern Ireland. Political Psychology, 28(1), 33-52.

Muldoon, O., Trew, K., \& Devine, P. (2020). Flagging difference: National identity and emotional responses to national flags. Journal of Applied Social Psychology, 50(5), 265-275.

Muldoon, O. T., Trew, K., Todd, J., Rougier, N., \& McLaughlin, K. (2007). Religious and national identity after the Belfast good Friday agreement. Political Psychology, 28 (1), 89-103.

Neville, F. G. (2011). The experience of participating in crowds: Shared identity, relatedness and emotionality. Ph.D. Thesis: University of St Andrews.

Neville, F. G., \& Reicher, S. D. (2018). Crowds, social identities and the shaping of everyday social relations. In C.J. Hewer \& E Lyons (Eds.), Political Psychology: A Social Psychological Approach, (pp. 231-252). Chichester, UK: Wiley.

O'Donnell, A. T., Muldoon, O. T., Blaylock, D. L., Stevenson, C., Bryan, D., Reicher, S. D., \& Pehrson, S. (2016). 'Something that unites us all': Understandings of St. Patrick's Day parades as representing the Irish national group. Journal of Community \& Applied Social Psychology, 26(1), 61-74.

Pehrson, S., Stevenson, C., Muldoon, O. T., \& Reicher, S. (2014). Is everyone Irish on St Patrick's Day? Divergent expectations and experiences of collective self-objectification at a multicultural parade. British Journal of Social Psychology, 53(2), 249-264.

Pidgeon, N., \& Henwood, K. (1997). Using grounded theory in psychological research. In N. Hayes (Ed.), Doing qualitative analysis in psychology (pp. 245-274). Hove: Psychology Press.

Prayag Magh Mela Research Group. (2007). Collective identity, collective experience and the impact of participation in a mass event. Psychological Studies, 52(4), 293-301.

Reicher, S. D. (2011). Mass action and mundane reality: An argument for putting crowd analysis at the centre of the social sciences. Contemporary Social Science, 6, 433-450.

Reicher, S. D. (2012). From perception to mobilization: The shifting paradigm of prejudice. In J. Dixon \& M. Levine (Eds.), Beyond prejudice: Extending the social psychology of conflict, inequality and social change (pp. 27-47). New York, NY: Cambridge University Press.

Reicher, S. D., \& Haslam, S. A. (2010). Beyond help: A social psychology of collective solidarity and social cohesion. In S. Stürmer \& M. Snyder (Eds.), The psychology of 
pro-social behavior: Group processes, intergroup relations, and helping (pp. 289-309). Oxford: Blackwell.

Ross, A. (2007). Multiple identities and education for active citizenship. British Journal of Educational Studies, 55(3), 286-303.

Skinner, J., \& Bryan, D. (2015). Consuming St. Patrick's Day. Newcastle, UK: Cambridge Scholars Publishing.

Smyth, J. (2017). Remembering the troubles: Contesting the recent past in Northern Ireland. Notre Dame, IN: University of Notre Dame Press.

Stevenson, C., \& Muldoon, O. T. (2010). Socio-political context and accounts of national identity in adolescence. British Journal of Social Psychology, 49(3), 583-599.

Strauss, A., \& Corbin, J. (1998). Basics of qualitative research: Techniques and procedures for developing grounded theory. Thousand Oaks, CA: Sage.

Todd, J. (2005). Social transformation, collective categories, and identity change. Theory and Society, 34(4), 429-463.

Turner, J. C. (1991). Social influence. Pacific Grover, CA: Brooks/Cole.

Turner, R. H., \& Killian, L. M. (1972). Collective behaviour (2nd ed.). Englewood Cliffs, NJ: Prentice-Hall.

van Zomeren, M., Leach, C. W., \& Spears, R. (2012). Protesters as "passionate economists": A dynamic dual pathway model of approach coping with collective disadvantage. Personality and Social Psychology Review, 1-20. doi:10.1177/ 1088868311430835

White, T. J., \& Marnane, D. (2016). The politics of remembrance: Commemorating 1916. Irish Political Studies, 31(1), 29-43.

Willig, C. (2001). Introducing qualitative research in psychology: Adventures in theory and method. Buckingham: Open University Press. 